\title{
Dylematy i paradoksy identyfikacji ideologicznych w okresie transformacji
}

DOI: $10.35757 /$ CIV.2010.12.04

\section{Wprowadzenie}

Przy analizie hierarchii wartości ideologicznych polskich partii politycznych niezmiennie napotyka się trudność przyporządkowania jednej ideologii politycznej na wyłączność tylko określonej partii. I odwrotnie - żadna $z$ formacji politycznych nie daje się jednoznacznie zaklasyfikować w ściśle określone ramy jednej ideologii. Zaszeregowanie podmiotów politycznych do jednego zbioru ideologicznego, w okresie polskiej transformacji, jest tym bardziej trudne, że demokratyzacja życia społeczno-politycznego obfitowała $\mathrm{w}$ wiele wydarzeń, które pobudzały ludzkie emocje. Ideologie wędrowały po różnych obozach politycznych, czasami adoptowane były na dłuższy czas, a czasami - w wyniku doraźnych interesów - szybko odrzucane. Niemniej można się podjąć próby wyznaczenia głównych nurtów ideologicznych towarzyszacych polskiemu życiu politycznemu. Ilustracja tego zamierzenia jest niniejsze opracowanie, które ma za zadanie ukazanie charakterystycznych nurtów, determinujących zarówno profile partii politycznych, jak i ich programy.

Marek Górka - absolwent politologii na Uniwersytecie Mikołaja Kopernika w Toruniu, doktorant na Wydziale Nauk Politycznych Akademii Humanistycznej im. Aleksandra Gieysztora w Pułtusku. 
Naturalnie nasuwa się potrzeba porównania stanowisk zajmowanych przez obozy o tych samych korzeniach politycznych, a także konfrontacji motywów poruszanych przez środowiska o odmiennym rodowodzie politycznym. Kwestia, nad którą warto się zastanowić sa różnice w obrębie jednej grupy partii o wspólnej tradycji politycznej oraz stopień bliskości ich programu do określonego zbioru idei. Co łączy i integruje partie wywodzace się $z$ tego samego pnia politycznego? Jak mocne sa to więzi, czy na tyle, aby można było stworzyć wspólną koalicję? Czy na podstawie analizy poruszanych tematów możliwa jest identyfikacja polityczna oraz odgórna klasyfikacja partii pod względem tradycyjnego układu prawica-lewica?

Mimo braku kontynuacji organizacyjnej partie polityczne za każdym razem konsekwentnie krocza tym samym torem wyznaczonym jeszcze w okresie rodzącego się pluralizmu politycznego, czego dowodem współcześnie jest posługiwanie się identycznymi sloganami $\mathrm{w}$ procesie rywalizacji politycznej. Można łatwo dostrzec, iż istnieje pewien stały konglomerat ideologiczny, który bez przerwy jest używany przez formacje polityczne. Dlatego możliwe jest na przykład postawienie tezy o kontynuacji podziałów politycznych w latach 2005-2007 na tle rywalizacji politycznej $z$ okresu lat dziewięćdziesiątych. Niniejszy tekst jest zatem próba ustalenia najważniejszych i najistotniejszych motywów, które wyznaczaja przestrzeń ideologiczna, w jakiej poruszaja się partie polityczne.

Kwestie takie jak między innymi przynależność do wartości kulturowo-religijnych, postrzeganie relacji między jednostką a wspólnota, interpretacja stosunków między podmiotami gospodarczymi a państwem stanowia punkty nawigacyjne dla badaczy, które ułatwiają określenie położenia partii $\mathrm{w}$ przestrzeni politycznej. Przez dwadzieścia lat polskiej transformacji można było wyodrębnić formację poruszająca się w ramach konserwatyzmu światopogladowego oraz etatystycznej ekonomii, a także druga grupę - opowiadajaca się za liberalizmem na poziomie światopoglądowym i ekonomicznym. Polska prawica stanowi niezwykle skomplikowa- 
ny zbiór poglądów, często o przeciwstawnych ideach politycznych. Można spotkać środowiska odwołujące się do wartości takich jak naród, religia, tradycja, konserwatyzm obyczajowy, dystans wobec międzynarodowych procesów integracyjnych. Istnieja również nurty przeciwstawne, akcentujace liberalizm światopoglądowy, podkreślające kosmopolityzm jako szansę poprawy sytuacji w kraju, i tylko gdzieś daleko pobrzmiewają echa religijne, które stanowia raczej punkt odniesienia niż sztywne nakazy postępowania. Okazuje się, że podział na dwa nurty w obozie postsolidarnościowym jest ponadczasowy i przy okazji kolejnych wyborów każdy $z$ nich znajduje odzwierciedlenie zarówno $\mathrm{w}$ postaci elektoratu, jak i reprezentacji parlamentarnej.

Po ujawnieniu istnienia pewnej kontynuacji przez partie polityczne zarówno nurtów ideologicznych, jak i treści programowych istotne wydaje się postawienie pytania o zasadność twierdzeń na temat przełomu politycznego w latach 2005 i 2007 czy też podanie w watpliwość metafory „konserwatywnej fali” używanej w języku publicystycznym ${ }^{1}$.

Skrywane w okresie podziemnej opozycji lat osiemdziesiatych wartości oraz przekonania znalazły w rzeczywistości demokratycznej na tyle podatny grunt, że na trwałe wpisały się $\mathrm{w}$ polski krajobraz polityczny. Można dostrzec pewną grupę doktryn, które posłużyły jako składnik budowy tożsamości partyjnej. Wydobyte na światło dzienne wartości religijne, narodowe oraz kwestie historyczno-kulturowe można potraktować jako zalązek pewnych idei, które $z$ czasem, w wyniku debat publicznych, rozwinęły się na tyle, że stały się fundamentalnymi wyznacznikami wielu partii politycznych. Wypada również zauważyć, że po prawej stronie sceny politycznej do roku 2005 brakowało ciagłości instytucjonalno-organizacyjnej, mimo to pozostała kontynuacja pewnych myśli i po-

\footnotetext{
1 Termin „konserwatywna fala” został użyty przez Michała Krzymowskiego i Marcina Dzierżanowskiego w artykule Popis Tuska, „Wprost” 2007, nr 43, s. 6. Autorzy, powołując się na badania prof. Janusza Czapińskiego, stwierdzili, że: „Bezprecedensowe zwyciestwo PO i lepszy niż w poprzednich wyborach wynik PiS to dowód na to, że w ostatnich latach polskie społeczeństwo staje się coraz bardziej konserwatywne".
} 
glądów, które ujawniły się w trakcie pierwszych miesięcy III RP. Uaktywniające się za każdym razem spory ideowe kładły się cieniem na proces konsolidacji prawej strony sceny politycznej, a także podtrzymywały podziały w życiu politycznym.

W tym znaczeniu można stwierdzić, iż obecne partie polityczne sa spadkobiercami podmiotów $z$ początku polskiej transformacji. Jednocześnie należy przyznać, że tylko dwie partie nieustannie miały swa reprezentację $\mathrm{w}$ parlamencie przez całe dwudziestolecie. Na powierzchni życia politycznego nieprzerwanie utrzymywał się lewicowy Sojusz Lewicy Demokratycznej oraz agrarne Polskie Stronnictwo Ludowe, co oczywiście nie oznacza, że obecność określonych nurtów prawicowych była krótkotrwała lub ich znaczenie odeszło w zapomnienie. Mimo zmiany szyldów politycznych, $\mathrm{w}$ przestrzeni politycznej zajmowanej przez partie postsolidarnościowe można dostrzec kontynuację poglądów zarówno na poziomie tożsamościowym, ideowym, jak i personalnym.

\section{Podziały historyczno-polityczne}

Przez dwudziestoletni okres transformacji dostrzegalna jest niechęć między stroną postsolidarnościową a postkomunistyczna. Wzajemna antypatia wynika $z$ zaszłości historycznych i przekłada się na odmienne postrzeganie okresu PRL przez obie strony konfliktu. Stosunek do minionego systemu oraz jego spadkobierców politycznych stawał się często nie tylko tematem kampanii wyborczych, ale także głównym elementem tożsamości partyjnej. $Z$ ta jednak różnica, że odczuwana wrogość między poszczególnymi partiami postsolidarnościowymi była równa, a czasem nawet większa niż w relacjach ze środowiskiem postkomunistycznym.

Pierwsze partie postsolidarnościowe powstałe po 1989 roku (w okresie między wyborami czerwcowymi 1989 roku, a grudniem 1990 roku, między innymi Zjednoczenie Chrześcijańsko-Narodowe i Porozumienie Centrum) skupiały się wokół idei dekomunizacji. 
Dylematy i paradoksy identyfikacji ideologicznych...

Stosunek do minionego ustroju kształtował tożsamość obozu postsolidarnościowego, a także postkomunistycznego, który stał się naturalnym spadkobierca i adwokatem dawnego systemu. Ocena okresu PRL, ale także odmienna interpretacja początków nowej rzeczywistości, zaczęła polaryzować rodząca się scenę polityczną. $Z$ czasem zaczęły się wyróżniać środowiska po prawej stronie sceny politycznej, które otwarcie kwestionowały porozumienia Okragłego Stołu, upatrując w nich element zdrady narodowej. Obrońcami kompromisu zawartego przy Okragłym Stole były środowiska polityczne skupione wokół premiera Tadeusza Mazowieckiego oraz formacji lewicowej grupującej się wokół ówczesnej koalicji SLD.

Tym, co poróżniło powstające partie był także rozdźwięk na poziomie rodowodu (nie tyle politycznego, ile kulturowo-środowiskowego). Nastapił proces akcentowania odrębności grup w ramach Solidarności. Pierwszy obóz składał się $z$ robotników oraz reprezentował postawy antyelitarne $i$ antyinteligenckie. Jego politycznym ucieleśnieniem był Lech Wałęsa. Drugi obóz natomiast był zupełnym przeciwieństwem pierwszego, składał się przede wszystkim $z$ inteligencji oraz elit opozycyjnych. Przepaść, jaka wyrosła między obiema grupami była wynikiem alienacji elit solidarnościowych, a także poczucia powszechnego zagubienia w nowej rzeczywistości oraz rosnącej niechęci społeczeństwa do rządów solidarnościowych, wywołanej zmianami gospodarczymi: „[...] przekształcanie gospodarki - obok dławienia inflacji - uderzało w ludzi. Zaczęły się pojawiać bezrobocie i dramatyczne ubożenie dużej części Polaków. Wałęsa i prawica stanęli przed dylematem: bronić gospodarczej marszruty atakowanego przez siebie ze względów politycznych rządu czy stanąc na czele sprzeciwu wobec kosztów społecznych przemian" ${ }^{2}$. Stosunek do przemian określanych hasłowo jako „plan Balcerowicza” stał się linią demarkacyjną polskich partii politycznych. Kosztowne przemiany polskiej gospodarki w kierunku kapitalistycznym podzieliły społeczeństwo na zwolenników oraz

2 A. Domosławski: Czasy burzy i naporu, „Gazeta Wyborcza” 1997, nr 185, s. 8. 
przeciwników idei wolnego rynku, a jednocześnie wywołały podział na prawicę etatystyczna i liberalna ${ }^{3}$.

Tysiące Polaków, którzy popierali Solidarność w latach osiemdziesiątych, oczekiwało, że „[...] wraz $z$ upadkiem komunizmu szybko nadejda nowe lepsze czasy, przede wszystkim zaś poprawa materialnych warunków życia. $Z$ ich punktu widzenia po $1989 \mathrm{r}$. nic się nie zmieniło lub zmieniło się niewiele. Czasami wręcz sytu-

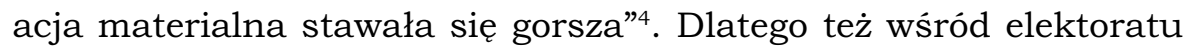
solidarnościowego zrodziło się zapotrzebowanie na pojawienie się reprezentacji prawicowej dystansującej się od reform rządu Tadeusza Mazowieckiego. Postępująca frustracja, a wraz $z$ nia radykalizacja poglądów politycznych, stawały się za każdym razem zarzewiem nowych radykalno-populistycznych formacji politycznych. W odczuciu społecznym odpowiedzialność za ciężar przemian ponosiła Solidarność. Część środowisk solidarnościowych, aby odsunać od siebie ostrze krytyki, dystansowała się wobec zachodzacych zmian, wskazując jednocześnie winnych oraz radykalizując swe postulaty. Postawa antyliberalna i antyinteligencka $\mathrm{w}$ samym środowisku solidarnościowym stawała się faktem. Oczywiście zamęt gospodarczy, utrata stabilizacji socjalnej, poczucie osamotnienia wśród społeczeństwa oraz wysokie koszty transformacji coraz bardziej dokuczały, dając tym samym siłę postkomunistycznej lewicy. Lewa strona podjęła tematyke gospodarczo-społeczną, rehabilitując jednocześnie okres PRL jako czas bezpieczeństwa i stabilności socjalno-ekonomicznej.

Rozbudzanie nadziei wraz $z$ nastawieniem roszczeniowym stały się orężem w walce wyborczej radykalnej prawicy, która przy okazji każdej rywalizacji przybierała różne wcielenia organizacyjno-polityczne. Jednak główna myśl antyliberalna pod względem zarówno etyczno-kulturowym, jak i ekonomicznym pozostawała jednakowa. Wrogość wobec przemian wolnorynkowych stała się

\footnotetext{
3 P. Boski: O dwóch wymiarach lewicy-prawicy na scenie politycznej $i$ wartościach politycznych polskich wyborców, w: J. Reykowski (red.): Wartości i postawy społeczne a przemiany systemowe. Szkice z psychologii politycznej, Instytut Psychologii PAN, Warszawa 1993, s. 62. 4 A. Domosławski: Czasy burzy..., s. 8.
} 
na tyle ogromna, że część środowisk postsolidarnościowych pojęcie „liberalizmu” zaczęła utożsamiać $z$ komunizmem, a członków partii politycznych przyznajacych się do poglądów liberalnych zaczęto traktować na równi $z$ byłymi działaczami PZPR. Konsekwencja tej percepcji była stale utrzymująca się niechęć polskiej prawicy do zwolenników liberalizmu, mających de facto te same korzenie solidarnościowe. Kulminacyjnym przejawem takiego postrzegania stało się hasło $z$ kampanii wyborczej z 2005 roku o podziale na Polskę „solidarną" i „liberalna”.

Polska prawica skupiona w ruchu Solidarność musiała zaangażować się w odgrywanie roli $z$ góry jej przypisanej, a mianowicie rekonstrukcji gospodarki oraz wzięcia na siebie ciężaru przestawienia całego systemu ekonomicznego $z$ gospodarki planowej na tory gospodarki wolnorynkowej. Zadanie okazało się tym trudniejsze, że przeprowadzajac zmiany, musiała hamować tendencje roszczeniowe we własnych szeregach.

Charakterystyczną cechą ruchu związkowego były postawy roszczeniowo-etatystyczne. „Solidarność była [...] wprawdzie [ruchem] demokratycznym i antyautorytarnym, lecz na pewno nie liberalnym; była ona raczej wyrazem socjalistycznego populizmu, $\mathrm{w}$ gruncie rzeczy bardziej związanym $z$ komunizmem niż racjonalne, światłe i zmierzające $\mathrm{w}$ stronę coraz większej liberalizacji elity polityczne i gospodarcze PRL" .

Mentalność postkomunistyczna, od której nie byli wolni także członkowie Solidarności, a która formowana była przez ponad czterdzieści lat, dała o sobie znać przy okazji wielu protestów już w okresie III RP. Inną konsekwencja państwa opiekuńczego było pojawienie się podatnego gruntu dla formacji populistycznych, które przybrały inne formy organizacyjne poza strukturami NSZZ „Solidarność”.

Ogromne koszty transformacji, jakie poniosło społeczeństwo, zrodziło strach przed reformami gospodarczymi. Niechęć do prze-

Z. Krasnodębski: Wizja polityki w Solidarności 1980-81 oraz w III Rzeczypospolitej, w: R. Bäcker (red.): Solidarność dwadzieścia lat później, Arcana, Kraków 2001, s. 128. 
kształceń w kierunku gospodarki wolnorynkowej ujawniła się również $\mathrm{w}$ elitach politycznych, co było podyktowane spadkiem sympatii wśród wyborców oraz wzrastająca krytyka rządów solidarnościowych. $Z$ liberalizmem było podobnie jak $z$ demokracją: na początku transformacji nikt nie wiedział do końca, co oznaczaja te hasła. Tak naprawdę, nikt też nie wiedział, czego się można spodziewać i jakie skutki przyniosa zmiany polityczne. W pewnym sensie był to eksperyment: próbowano zaszczepić idee, które nigdy do tej pory nie miały okazji zakorzenić się w polskiej rzeczywistości. Postulaty liberalne były raczej kojarzone i utożsamiane $z$ pluralizmem politycznym, wolnością słowa oraz poziomem i stylem życia zachodniego. Idee te były siła opozycji politycznej $z$ lat osiemdziesiatych i stanowiły podstawę programową rodzacych się partii politycznych na progu III RP.

Czy można uznać, że polski liberalizm ma źródła w postulatach mas czy też że pochodzi odgórnie, ze strony elit? Ideologia liberalna $\mathrm{w}$ polskich warunkach raczej nie spotyka się $z$ dużym aplauzem społecznym. Po pierwsze dlatego, że mentalność społeczna jest ukształtowana roszczeniowo i oczekuje od państwa więcej niż ono może dać. Po drugie, bolesne i kosztowne zmiany na początku lat dziewięćdziesiątych, pod szyldem reform liberalnych, stały się skutecznym straszakiem dla ludzi przed tego typu inicjatywami pod szyldem liberalnym. Po trzecie, społeczeństwo polskie jest na ogół biedne i nie stanowi podatnego gruntu do budowy pozycji dla partii liberalnej. Dlatego całkiem zrozumiałe może się wydawać odejście po 2005 roku Platformy Obywatelskiej od jednoznacznego wizerunku partii liberalnej w kierunku formacji zdolnej pomieścić również inne postulaty, nacechowane wrażliwością społeczna. PO zrezygnowała $z$ jednoznacznego wizerunku partii liberalnej, stała się wyrazicielka zbioru idei, w którym każdy wyborca znajdzie coś miłego dla siebie. Po czwarte, elity polityczne nastawione sa niechętnie do wstrząsów i radykalnych działań, które moga przynieść nieoczekiwane konsekwencje dla ich egzystencji politycznej. Toteż tylko niektóre formacje polityczne miały na tyle 
odwagi, aby inicjować dynamiczne procesy przemian gospodarczych.

$Z$ kolei polskiej lewicy, zbudowanej na gruzach partii komunistycznej, przypadła rola krytyka i oportunisty wobec zmian gospodarczych. Strona postkomunistyczna trafnie wyczuła zmęczenie społeczne przebudowa polskiej gospodarki, a także dostrzegła zapotrzebowanie społeczne na bezpieczeństwo socjalne. Dlatego też używała w dyskursie politycznym haseł odwołujacych się do spokoju, bezpieczeństwa i równowagi. Posługując się także społecznymi sentymentami do czasów PRL, silnie podkreślała swoja ciagłość i spuściznę minionego okresu, co spotykało się $z$ dużym oddźwiękiem w społeczeństwie.

Innym $z$ kolei podziałem wywołującym wiele emocji i polaryzującym scenę polityczna jest spór o miejsce i rolę, jaką miałby pełnić Kościól katolicki. W okresie PRL był on jedyna instytucja niezależna od władz państwowych oraz niekwestionowanym partnerem (w zależności od okresu) i strona w rywalizacji $z$ władzami, a także ostoją i schronieniem dla opozycji. Oczywiście, zaangażowanie Kościoła w życie publiczne w PRL było ogromne, lecz po przełomie roku 1989 jego rola stała się często kontrowersyjna. Kwestia miejsca Kościoła w III RP podnoszona była przez niemal wszystkie partie. Najbardziej było to dostrzegalne wśród ugrupowań, które otwarcie podzielały poglądy katolickie, przyznawały się do sympatii i bliskości kulturowo-etycznej. Tożsamość polityczna takich partii była niemal pasem transmisyjnym nauki i poglądów hierarchii kościelnej. Na drugim biegunie pozostawały środowiska lewicowe, które propagowały świecki model państwa, wykorzystując sentymenty i niedawna pamięć swojego zaplecza wyborczego. Między tymi biegunami znajdowały się formacje, które, propagując świecki model państwa, wyrażały sympatię do Kościoła, akcentując bardziej poszanowanie wzajemnych interesów i pokojowe współistnienie. Wyodrębniony podział na samym wstępie polskiego parlamentaryzmu okazał się niezwykle żywotny, należy więc przypuszczać, że $z$ pewnością utrzyma się jeszcze przez wiele lat. 
„Źródła podziałów w zwycięskim obozie "S" sięgaja lat 70., kiedy to w opozycji wyodrębniły się - w skrócie - dwa nurty: demokratyczno-laicki (większość środowiska KOR-u, czyli w prawicowym języku "lewica laicka") oraz narodowo-niepodległościowy (Ruch Obrony Praw Człowieka i Obywatela, KPN [Konfederacja Polski Niepodległej], Ruch Młodej Polski; też środowisko pisma "Głos" skupione wokół Antoniego Macierewicza). Te stare podziały i animozje $z$ wielokrotna siła odżyły w wolnej Polsce"6.

Wraz $z$ akcentami religijnymi ujawniły się również hasła i treści narodowotradycjonalistyczne. Przywiąanie do wartości narodowych, a także niechęć połączoną $z$ podejrzliwością i obawa o wykupienie ziem lub zawłaszczenie majatku narodowego przez obcych akcentowały takie formacje jak Zjednoczenie Chrześcijańsko-Narodowe, Wyborcza Akcja Katolicka, Ruch Odbudowy Polski, część środowiska Akcji Wyborczej Solidarność, a następnie Liga Polskich Rodzin oraz Samoobrona. Po kampanii wyborczej w 2005 roku nie było wolne od sceptycyzmu do procesów integracyjnych także Prawo i Sprawiedliwość.

\section{Między stagnacją a dynamizmem}

W stylu działania i sprawowania władzy przez polskie formacje polityczne można wyszczególnić grupę partii o bezkompromisowej, radykalnej postawie wobec minionej oraz zastanej rzeczywistości. Zapał rewolucyjny był szczególnie widoczny wśród partii fundamentalnej prawicy, jak Liga Polskich Rodzin, oraz wśród partii trzecich, to znaczy nie majacych korzeni ani solidarnościowych, ani PZPR-owskich; jako modelowy przykład może posłużyć Samoobrona. Natomiast wśród partii politycznych o rodowodzie postsolidarnościowym za ewolucyjnymi i stopniowymi zmianami opowiadały się środowiska zajmujące polityczne centrum. Przez wiele

6 Ibidem, s. 128. 
lat wizerunek partii racjonalnej i stonowanej miała Unia Wolności, a przedtem Unia Demokratyczna. Po wyborach parlamentarnych 2007 roku dominująca rolę w politycznym centrum zajęła Platforma Obywatelska, która jest tylko w pewnym stopniu kontynuatorka polityczna partii Tadeusza Mazowieckiego i Leszka Balcerowicza. Umiarkowany i kompromisowy styl działania oraz dystans wobec radykalnych i nieprzewidywalnych rządów cechuje również lewą stronę i jej głównego przedstawiciela - Sojusz Lewicy Demokratycznej.

Dokonując skrótowej analizy porównawczej, można opisać przestrzeń praktyki politycznej poprzez dwa bieguny. Pierwszy z nich reprezentuje działania gwałtowne, a nawet rewolucyjne, widoczne przede wszystkim wśród radykalnych formacji prawicowych. Drugi biegun odpowiada działaniom stonowanym, kompromisowym i zachowawczym - zauważalny jest zarówno po stronie środowisk postsolidarnościowych, jak i postkomunistycznych. Taki podział, odnoszacy się do partii politycznych, przebiega w zupełnie odmienny sposób niż tradycyjne linie podziału. Oczywiście nie można odmówić innowacyjności i chęci modernizacji kraju formacjom lewicowym, ale gwałtowny charakter wprowadzania zmian $\mathrm{w}$ życie i przekonanie o poczuciu misji reprezentuje $\mathrm{w}$ znacznym stopniu - przy sterze rządów - prawica. Pod tym kątem obóz postsolidarnościowy nie jest jednolity. Jeśli chodzi o prawą stronę sceny politycznej, można wyróżnić dwa nurty o odmiennych sposobach działania. Mamy więc $z$ jednej strony środowiska akceptujące radykalizm w działaniu, a nawet rewolucyjność, która także przejawia się $\mathrm{w}$ postulatach roszczeniowo-rozliczeniowych. Kontrowersyjność takich zamierzeń idzie $\mathrm{w}$ parze $\mathrm{z}$ kontestacja dotychczasowych przemian polityczno-gospodarczych. Wydarzenia takie jak np. Okragły Stół czy odwołanie rządu Jana Olszewskiego stały się inspiracją niezliczonych teorii spiskowych. Przedstawiane sa zazwyczaj jako zmowa elit lub zdrada narodowa. Hasła o walce $z$ układami były na tyle żywotne, że stały się fundamentem ideologicznym projektu IV RP. 
Drugie skrzydło postsolidarnościowe jest raczej dalekie od chęci wymierzania sprawiedliwości dziejowej oraz sceptyczne wobec formułowania jednoznacznych i kontrowersyjnych sąów. Cechuje je raczej umiar w sferze wartości, co oczywiście przekłada się na postrzeganie relacji między państwem i Kościołem. W tej kwestii partie centroprawicowe zazwyczaj postuluja kompromis oparty na zgodnym współistnieniu. Nie podkreślają także w swych deklaracjach wartości narodowych, choć oczywiście ich nie negują. Integracji $z$ Unią Europejska nie postrzegają w kategoriach zagrożenia dla interesu narodowego, lecz jako szansę dla rozwoju gospodarczego kraju. W tych przypadkach istnieje spora zbieżność poglądów między partiami liberalnymi o korzeniach postsolidarnościowych a środowiskiem postkomunistycznym, reprezentowanym głównie przez Sojusz Lewicy Demokratycznej. Co więcej - oprócz podobnej wizji modelu państwa - istnieje między nimi bliskość stylu działania w polityce. Otóż oba środowiska, mimo odmiennej genezy, charakteryzuja się dość duża przewidywalnościa oraz pewnościa co do stosowania i wprowadzania w życie poglądów w okresie swych rządów.

Analizując styl rządów po 1989 roku, można wysnuć wniosek, iż strona postsolidarnościowa częściej była inicjatorem zmian niż lewa strona sceny politycznej. Schemat zbudowany na zasadzie, iż to prawica modernizuje życie gospodarczo-społeczne, a po niej przychodzi lewica, która poniekąd daje wytchnienie i odprężenie od ciężaru zmian, wynika także $z$ kontekstu, w jakim znalazł się obóz solidarnościowy. U progu rodzącej się transformacji była to siła, która wyznaczyła kierunki przebudowy państwa oraz podjęła się ciężaru transformacji systemu polityczno-gospodarczego w kraju.

Wyborcy, głosując na lewicę, z pewnością częściej kierowali się potrzeba spokoju i stabilizacji $\mathrm{w}$ polityce oraz gospodarce. SLD, jako główny przedstawiciel lewicy, starał się jak najbardziej zamanifestować swój sceptycyzm wobec radykalizmu oraz udowodnić własna przewidywalność polityczną. Po rządach prawicy wyborcy za każdym razem wyrażali swoje rozczarowanie wobec kosztownych 
Dylematy i paradoksy identyfikacji ideologicznych...

perturbacji spowodowanych reformami ekonomiczno-społecznymi, oddając głos na formację zapewniająca stabilność polityczno-gospodarczą. Jednak po czterech latach społeczeństwo dostrzegało potrzebę dokonania koniecznych reform, do których przeprowadzenia odwage miała prawica.

Śledząc wybory parlamentarne, można dojść do wniosku, że główną przyczyną alternacji sterów rządu jest społeczna potrzeba zmiany. Polscy wyborcy szybko się zniechęcaja i zrażaja do rządzacych, co skutkuje potrzebą zmiany uczestników polityki.

\section{Siła negacji politycznej}

Mimo tradycyjnej linii podziału lewica-prawica podmioty polityczne zaczęły się poruszać $\mathrm{w}$ przestrzeni wyznaczonej ramami konfliktów politycznych. Opowiedzenie się za określoną wartościa powodowało pojawianie się oponenta politycznego. W myśl tej zasady artykułowanie wartości na przykład indywidualistycznych wywoływało automatyczny protest w postaci obecności idei odwołujących się do zbiorowości jako wartości nadrzędnej. Podobnie było w sytuacji akcentowania w dyskursie politycznym tożsamości narodowo-katolickiej, która także generowała przeciwstawne postulaty (na przykład świecki model państwa). Akceptacja procesów globalizacji oraz popularyzacja pogląoów kosmopolitycznych zrodziła nieufność oraz sceptycyzm, co w oczywisty sposób zmotywowało polityków do popierania tradycji narodowych. Nastapił także konflikt interesów między elitami a masami, za którym kryły się kolejne podziały na wyborców $z$ wielkich miast i $z$ prowincji oraz na młodych i starych. Postrzegając rywalizacje polityczną w sposób dualistyczny, można zbudować szerokie spektrum semantyki politycznej, wokół której poruszają się formacje polityczne. Oczywiście wszystkich tych podziałów nie da się w wyraźny i jednoznaczny sposób zawrzeć w podziale na zwolenników tradycji postsolidarnościowej lub postkomunistycznej. Trudności potęguja również same 
partie polityczne, których zajmowane stanowiska są odmienne, niż wynikałoby to $z$ przynależności do określonej ideologii.

Każde wybory w III RP przynosiły zmianę partii rzadzacej, a każda nowa ekipa rządząca była zaprzeczeniem poprzedniej. Czy więc negacja jest głównym instrumentem zmiany władzy i podstawowym narzędziem budowy tożsamości politycznej? Jak się wydaje, jest to immanentna zasada systemu demokracji. Warto jednak się zastanowić, czy spory i kłótliwość nie stały się wyłącznym elementem w relacjach politycznych oraz czy negacja nie stała się wartościa sama $\mathrm{w}$ sobie? $\mathrm{W}$ takich sytuacjach każdy podmiot polityczny określa własna identyfikację poprzez negację przeciwnika. „Jeśli bowiem przyjrzymy się bliżej dwudziestowiecznym ideom, zawsze okaże się, iż formułowane były przeciwko czemuś lub komuś: liberalizm przeciwko konserwatyzmowi, komunizmowi, socjalizmowi czy faszyzmowi, konserwatyzm i faszyzm - przeciwko komunizmowi i liberalizmowi, komunizm - liberalizmowi i konserwatyzmowi, socjalizm - komunizmowi i liberalizmowi. Pomiędzy tymi ideami przeplatały się koncepcje, które równie łatwo definiować przez negację: anty-semityzm, anty-kolonializm, kontr-rewolucja, kontr-kultura, i cokolwiek by one ze soba niosły, wyrastały one ze sprzeciwu wobec czegoś, były motywowane niezgoda na coś, a dopiero $\mathrm{w}$ drugim rzędzie starały się przedstawić wizje pozytywne"7.

Jak można zauważyć, spory polityczne zawsze były obecne wokół różnic programowych, doktrynalnych czy też ambicjonalno-personalnych. Alternatywne wizje sposobu działania, rozwiazywania problemów oraz ścierania się stanowisk zazwyczaj wynikają $z$ odmienności wyznawanych wartości. Jednak oprócz różnicy stanowisk opartych na podbudowie doktrynalnej istnieje jeszcze spora odmienność w opinii, powodowana przyczynami mniej zrozumiałymi dla odbiorcy. W systemie parlamentarnym niezwykle często pojawia się różnica stanowisk spowodowana działaniem

\footnotetext{
7 K. Karolczak: Od chadecji do syjonizmu. Szkice o myśli politycznej XX wieku, Wydawnictwo
} Elipsa, Warszawa 1996, s. 9. 
na przekór. Okazuje się, że jest to najczęstsza motywacja do sporów między rządem a opozycja.

Mimo dynamicznie zmieniających się formacji politycznych - w sensie ilościowym, organizacyjnym i personalnym - daje się zauważyć kontynuację pewnych motywów politycznych. Tym samym można przypuścić, iż mamy do czynienia ze stałą obecnością idei w życiu politycznym. Większość tematów politycznych, które rozpalały serca i wyobraźnie polskich wyborców przetrwała w niezmienionym znaczeniu, choć może kwestie te były wyrażane $\mathrm{w}$ innej frazeologii. Izolacjonistyczne nastawienie do innych krajów znalazło wyraz na przykład w retoryce Zjednoczenia Chrześcijańsko-Narodowego, które odgrzewało uprzedzenia antyniemieckie. Podejrzliwość wobec obcych wiele razy ujawniała się wśród radykalnych partii postsolidarnościowych, takich jak Wyborcza Akcja Katolicka, Katolicki Komitet Wyborczy „Ojczyzna”, Ruch Odbudowy Polski. Akcentowanie wartości narodowo-katolickich często miało na celu konfrontacyjne nastawienie wobec partii opowiadających się za zbliżeniem Polski z międzynarodowymi organizacjami polityczno-ekonomicznymi. W późniejszym czasie sprzeciw wobec przystapienia Polski do Unii Europejskiej ujawnił się w pełnej okazałości w postawie Ligi Polskich Rodzin. Ów sprzeciw stał się swoistym znakiem rozpoznawczym tej partii ${ }^{8}$.

Analizując treść tematów poruszanych przez partie, można zauważyć dwupoziomowość znaczeń, na których opieraja się argumenty polityczne. $Z$ jednej strony akcentowane sa cechy, które mają wskazać na bliskość i przywiązanie do pewnych uniwersalnych wartości (na przykład powszechnie akceptowanych wartości chrześcijańskich). $Z$ drugiej strony podkreśla się własną odrębność światopoglądową od reszty otoczenia politycznego, akcentujacc swą indywidualność oraz wyjątkowość poglądów. Obie warstwy tożsamości politycznej - zarówno ta uniwersalna, jak i ta indywidualistyczna - sa nieodzowną cechą każdej partii; każda prze-

8 J. Raciborski: Wybory i wyborcy, w: J.J. Wiatr i in. (red.): Demokracja polska 1989-2003, Wydawnictwo Naukowe Scholar, Warszawa 2003, s. 213-220. 
cież podkreśla pewne wartości ogólne, zapewniając jednocześnie, że jest jedynym ich gwarantem.

Zadziwiajace jest na przykład, jak w 2005 roku, podczas rywalizacji wyborczej, każda formacja - bez względu na rodowód polityczny - postulowała potrzebę naprawy mechanizmów funkcjonowania państwa. Hasło sanacji pojawiło się w wypowiedziach przedstawicieli wszystkich partii politycznych: od lewicowych do prawicowych. Podobnie było w 2007 roku: tematyka kampanii zrównywała partie zarówno $\mathrm{w}$ ich sensie zarówno personalnym, jak i światopoglądowym. Utworzony został charakterystyczny front zwolenników oraz przeciwników polityki Prawa i Sprawiedliwości.

W rzeczywistości okazuje się więc, że każda partia odwołuje się do wartości ogólnie akceptowanych i pożądanych. Można przypuszczać, że jest to jedyna stała i niezmienna cecha łącząca wszystkie partie polityczne, choć interpretacja znaczenia haseł pozostaje w gestii ich autorów. $Z$ pewnościa każdy $z$ wyborców jest za tym, aby państwo było praworządne i wszystkie mechanizmy funkcjonowania życia publicznego funkcjonowały zgodnie $z$ prawem. Każdy obywatel jest za sprawiedliwym sposobem redystrybucji dóbr, choć zupełnie na marginesie należy przyznać, że każdy inaczej definiuje tę sprawiedliwość. Każdy z pewnością ceni sobie wartości obywatelskie oraz własna wolność podejmowania decyzji, a także mniej lub bardziej akceptuje wartości chrześcijańskie (chociaż stosunek liczby wierzacych do praktykujacych jest kłopotliwy, zarówno kiedy weźmiemy pod uwagę liczbę praktykujących, choć niewierzacych, jak i w odwrotnym stosunku: liczby wierzacych lecz niepraktykujacych). Jak można zaobserwować, żadna $z$ partii nie krytykuje otwarcie wartości uniwersalnych, co więcej, każda $z$ partii je akceptuje. Gdzie więc tkwi różnica między formacjami politycznymi? Znakiem rozpoznawczym poszczególnych partii staja się specyficzny sposób działania podczas rządów, a także zarezerwowane hasła i tematyka. Idąc tym tropem, można także wyszczególnić pewne kwestie, które sa niejako zarezerwowane dla poszczególnych partii. Występująca wyjątkowość lub osobliwość 
polityczna $\mathrm{w}$ poruszanej tematyce decyduje o specyficznym wizerunku partii. Posługując się terminem użytym przez Xymenę Bukowską i Mikołaja Cześnika, należy stwierdzić, iż istnieje zjawisko zawłaszczania niektórych tematów przez ugrupowania polityczne niejako na wyłaczność ${ }^{9}$. W odbiorze społecznym jest to odczytywane $\mathrm{w}$ taki sposób, jak gdyby określona kwestia istniała tylko i wyłącznie w posiadaniu jednej partii.

Tak jest na przykład w przypadku Prawa i Sprawiedliwości oraz stosowanej przez tę partię retoryki praworząności. Partia braci Kaczyńskich - jeszcze pod szyldem Porozumienia Centrum - od samego początku stała na straży poszanowania praworządności, akcentując konieczność zmiany prawa karnego, co miało się wyrażać $\mathrm{w}$ surowszych karach dla przestępców ${ }^{10}$. Sprawiedliwość, w przypadku PiS, ujmowana jest zarówno w sensie porządku publicznego, jak i w pojęciu ekonomiczno-społecznym, oznaczajacym sprawiedliwy podział dóbr. Postulaty równej redystrybucji zysku gospodarczego znalazły podatny grunt wśród wyborców, którzy najdotkliwiej odczuli skutki transformacji. Nie bez znaczenia jest również przyjęta strategia wyborcza, która ma stanowić proste wyjaśnienie przyczyny wysokich kosztów przemian gospodarczych.

\section{Paradoksy tożsamości ideologicznych}

Analizując polski system partyjny, można dojść do wniosku, że żadna $z$ partii nie ma klarownego wizerunku politycznego, zgodnego $z$ przyjętymi podziałami ideologicznymi. Po prawej stronie sceny politycznej zawsze można było dostrzec środowiska akcentujące idee państwa opiekuńczego, co zgodnie $z$ tradycyjnymi podziałami nie mieści się $\mathrm{w}$ ramach wartości prawicowych. Podobna niespój-

9 X. Bukowska, M. Cześnik: Analiza treści programów wyborczych polskich partii politycznych 1991-2001, w: R. Markowski (red.): System partyjny i zachowania wyborcze: dekada polskich doświadczeń, Instytut Studiów Politycznych PAN, Fundacja im. Friedricha Eberta, Warszawa 2002, s. 271.

${ }^{10}$ J. Raciborski: Wybory i wyborcy, ibidem, s. 218. 
ność występuje także po lewej stronie. Można dojść do wniosku, iż okres rządów koryguje deklaracje polityczne, a praktyka rządzenia przestawia postulaty polityczne na zupełnie inne tory, rekonstruując program, którym posługiwało się zwycięskie ugrupowanie podczas kampanii wyborczej. W przypadku porażki wyborczej następowała również zmiana programu politycznego. Przegrane ugrupowania zazwyczaj radykalizuja swój język, a wraz z nim głoszone postulaty. Zmiana następowała również po stronie ugrupowania zwycięskiego, które, poniekąd idąc na kompromis $z$ koalicjantem politycznym, musiało również $\mathrm{w}$ okresie swych rządów uwzględniać kompromis programowy, zmuszający do wzięcia pod uwage postulatów ekonomiczno-społecznych partnera politycznego. Charakterystyczna jest również relacja między wielkościa i siła partii a zmiennościa jej programu. Okazuje się, że im mniejsze ugrupowanie lub im bardziej pozostające na marginesie politycznym, tym bardziej skłonne jest do radykalizmu politycznego. Natomiast im formacja jest większa oraz im bliższa centrum decyzyjnego lub sterów rządu, tym bardziej odżegnuje się od - jeśli formułowała je wcześniej - postulatów populistyczno-radykalnych. Pewien wpływ na taka sytuację mają standardy międzynarodowe w sferze ekonomiczno-gospodarczej, wynikające $z$ przynależności do organizacji międzynarodowych. Tym jednak, co zasługuje na podkreślenie jest fakt, iż żadna $z$ opcji politycznych, postępująca racjonalnie, nie może się sztywno trzymać wyznaczonej ideologii. Obecnie liberał nie może zaprzeczyć, iż obok wolnego rynku istnieje również potrzeba interwencji państwa, tak samo żaden rozumny socjalista nie zaprzeczy, iż mechanizmy wolnorynkowe sa potrzebne do sprawnego funkcjonowania gospodarki. W okresie transformacji, bez względu na przynależność ideologiczna ekip rządzących, każda $z$ partii starała się godzić elementy etatystyczno-socjalne $z$ wymaganiami gospodarki liberalnej. Żaden $z$ polityków, będąc przy władzy, nie może sobie pozwolić na stanowcze odrzucenie jednego $z$ poglądów.

Podziały w polskim systemie partyjnym przebiegaja w zupełnie odmienny sposób niż ten, który wytycza tradycyjna granica między 
lewica a prawicą. Radosław Markowski w jednoznacznie pejoratywny sposób wypowiada się na temat polskiego systemu partyjnego, określając wyborców mianem „hord partyjnych"11, a system partyjny nieco łagodniej jako „zbiorowisko partii” ${ }^{12}$ : „Systemowość zbioru partii to cecha wymagająca, a ostatnie kilkanaście lat polskich dokonań w tym zakresie nie upoważnia do bronienia tezy o ukształtowaniu się systemu partyjnego w naszym kraju"13.

Podziały, które zaistniały na polskiej scenie politycznej sa uwarunkowane specyficznym doświadczeniem zarówno $\mathrm{w}$ przestrzeni historyczno-politycznej, jak i kulturowo-psychologicznej. Dlatego zaistniał kłopot $z$ jednoznacznym umiejscowieniem polskich partii między biegunami politycznymi. Co więcej, obszar wartości ideologiczno-obyczajowych nie idzie $\mathrm{w}$ parze $z$ wartościami $\mathrm{w}$ sferze poglądów ekonomiczno-gospodarczych. Może to stanowić wyjaśnienie, dlaczego tak trudno osiagnąć konsens po prawej stronie sceny politycznej, a także dlaczego niektóre partie postsolidarnościowe sa zbliżone w określonych kwestiach do partii postkomunistycznych.

Obecnie coraz trudniej odnaleźć jednorodne bloki polityczne, gdyż każdy $z$ obozów partyjnych odwołuje się do różnych wartości i składa deklaracje, których celem jest zwiększenie liczby elektoratu. $Z$ tego też powodu przed badaczem chcacym uporządkować podziały polityczne, dokonać klasyfikacji tożsamości partii według wskazówek ideologicznych, piętrzą się trudności. „Nie ma partii idealnej, nie ma partii konsekwentnie prawicowej, konsekwentnie lewicowej. Nawet jeśli zdefiniujemy pojęcie prawicy i lewicy, to w każdej nauce coś nie będzie się zgadzało i trzeba dać sobie spokój z myśleniem o polityce w kategoriach ideału"14.

„Lewica” i „prawica” sa pojęciami dość elastycznymi i pojemnymi, które, mimo zmieniającej się rzeczywistości politycznej, sa nie-

\footnotetext{
${ }^{11}$ R. Markowski: Hordy, a nie elektorat, rozmawiała Agnieszka Kublik, "Gazeta Wyborcza” 2006, nr 96, s. 20.

${ }^{12}$ R. Markowski: System partyjny, w: L. Kolarska-Bobińska, J. Kucharczyk, J. Zbieranek, Demokracja $w$ Polsce 2005-2007, Instytut Spraw Publicznych, Warszawa 2007, s. 150.

13 Ibidem, s. 145

${ }^{14}$ A. Dudek (wypowiedź w dyskusji), w: M. Migalski (red.): Prawica w Polsce 1989-2005, Instytut Regionalny, Katowice 2005, s. 19.
} 
zwykle silnie zakorzenione $\mathrm{w}$ mentalności ludzkiej. Ich siła polega również na tym, że przystępując do opisu konstelacji politycznych, zawsze posługujemy się tymi pojęciami. Oczywiście nie sposób wyprzeć się ani odrzucić interpretacji sceny politycznej przez pryzmat podziału na prawicę i lewicę. "Pamiętajmy, że słowo "prawica" (podobnie jak i "lewica») nie jest desygnatem jakiegoś spójnego, jednoznacznego zjawiska politycznego. Nie ma żadnego "wzorca prawicy" (i lewicy) [...]. Życie polityczne jest tak bogate, że aby je opisać, trzeba wielu wymiarów. Podział "lewica" - "prawica" służy do uproszczonej charakterystyki zdecydowanie bardziej skomplikowanej rzeczywistości, ułatwia poruszanie się w niej osobom słabiej zorientowanym, pozwala widzom identyfikować się $z$ aktorami na politycznej scenie. [...] Stąd dezorientacja części komentatorów mówiących o "lewicowej prawicy" czy - rzadziej - "prawicowej lewicy""15.

Wielowymiarowość życia i złożoność jego procesów oraz skomplikowana natura nie tylko człowieka, ale także zachodzacych zmian oraz zjawisk zwiększa trudności w postrzeganiu wydarzeń. Okazuje się również, że percepcja świata tylko i wyłącznie w kategoriach zero-jedynkowych nie odzwierciedla w pełni złożoności problemów. $Z$ drugiej jednak strony natura ludzka jest skłonna do upraszczania rzeczywistości. Dualistyczny podział na prawice i lewice pozwala na uzyskanie orientacji w skomplikowanych procesach politycznych. Kategoryzuje również i uporządkowuje tożsamość partii politycznych, a także opisuje relacje między nimi.

W Polsce podział ideologiczny nabiera dodatkowego znaczenia. Przyporzadkowanie podmiotu do jednej ze stron automatycznie przywołuje pewne naleciałości historyczne. Oczywiście nie przesadza to wyraźnie o programie politycznym, ale stanowi pewien szyld informujacy o politycznym rodowodzie. Dwuwymiarowe postrzeganie życia ułatwia poruszanie się w skomplikowanym labiryncie rzeczywistości, choć często może prowadzić do mylnych sądów lub

${ }_{15}$ T. Żukowski (wypowiedź w dyskusji), ibidem, s. 40. 
stereotypów, które $z$ racji swej natury nie odzwierciedlają w pełni opisywanego świata. Obecne zróżnicowanie na gruncie identyfikacji religijnej, tożsamości historyczno-kulturowej, a także kwestii ekonomicznych oraz odmienności wynikającej $z$ podziałów demograficzno-geograficznych nie wpisuja się w tradycyjna dwuwymiarowość polityczną. „Analogicznie: jeśli ktoś jest antyklerykałem, to "oczywiście" jest wrogiem Kościoła, a nawet "osobistym wrogiem Pana Boga»? Niezupełnie, gdyż klerykałem może być ateista-oportunista, a $z$ kolei antyklerykałem człowiek żarliwie pobożny"16. Można stwierdzić, że opisywanie świata w sposób dualistyczny jest pożyteczne, lecz często bywa także niesprawiedliwe. Pójście na skróty powoduje oszczędność czasu, ale nie zawsze musi zbliżać do celu. Podobnie jest ze światłem: choć jest przezroczyste, należy pamiętać, że składa się z szerokiego spektrum kolorów, a każdy $z$ nich ma wiele odcieni.

Podział na prawicę i lewicę nie jest już wystarczający, aby w pełni odzwierciedlać rywalizację polityczną. Dla zrozumienia procesów zachodzących w polskiej polityce potrzebne sa schematy o wiele bardziej rozbudowane, w których uwzględniona jest złożoność procesów politycznych. Pojęcia „prawica” i „lewica” sa na tyle pojemne, że moga zawierać $\mathrm{w}$ sobie przeciwstawne postulaty polityczne. Dlatego należy ostrożnie poruszać się w meandrach polskiej polityki, co $z$ pewnościa nie jest łatwe i wymaga naukowej podejrzliwości.

W ciagu dwudziestu lat transformacji ujawniły się podziały, które do tej pory albo istniały na peryferiach życia politycznego, albo też dopiero co zrodzily się w wyniku nowych zjawisk ekonomiczno-społecznych. Różnorodne, często przeciwstawne poglądy dość łatwo ulegały absorpcji przez partie polityczne, co spowodowało powstanie ogromnej plataniny ideologicznej. Do takich tematów należy $z$ pewnością kwestia integracji europejskiej, która dopie-

\footnotetext{
${ }^{16}$ M. Karwat: Ucieczka przed tożsamościa. Antynomie i paradoksy identyfikacji polskich polityków i partii, w: J. Błuszkowski (red.): Dylematy polskiej transformacji, Dom Wydawniczy Elipsa, Warszawa 2007, s. 123.
} 
ro podczas procesu przemian polityczno-gospodarczych w Polsce zaczęła polaryzować scenę polityczna. Inne kwestie, których symptomy powoli sa dostrzegalne $\mathrm{w}$ polskim życiu politycznym, a które $z$ pewnościa przetasuja system partyjny, to zagadnienia $z$ pogranicza etyki i medycyny. Nieunikniony postęp medyczny $\mathrm{w}$ kontrowersyjnych kwestiach (na przykład zapłodnienia in vitro, klonowanie człowieka czy eutanazja) przyniesie obowiazek uregulowań prawnych, co pociagnie za soba przymus opowiedzenia się po jednej ze stron.

Warto również się zastanowić, ile jest motywów zaczerpniętych $z$ ideologii lewicowych przez partie uważające się za ugrupowania prawicowe, i odwrotnie - które kwestie prawicowe staja się inspiracja do budowy programów wyborczych przez partie zaliczające się do nurtu lewicowego. Innymi słowy, ile jest prawicy w lewicy, a ile lewicy $\mathrm{w}$ prawicy? Odpowiadając na to pytanie, warto powtórzyć, iż w polskiej rzeczywistości politycznej od dwudziestu lat nie było ani klarownej prawicy, ani klarownej lewicy, zarówno $\mathrm{w}$ sensie ideowym, jak i gospodarczym. Zawsze któryś $z$ elementów pochodził $z$ przeciwstawnego obozu, tworzac tym samym niespójna konstrukcję partyjną.

Partie często określają swą identyfikację polityczną opierając się na własnych korzeniach. Nierzadko zdarza się, że nie jest to do końca umotywowane potrzeba umocnienia własnej tożsamości, ale raczej chęcia przywłaszczenia sobie zasług lub nadinterpretacji udziału w pewnych wydarzeniach historycznych. Jest to zabieg o tyle latwy dla inspiratora, iż wydarzenia historyczne będące kamieniem węgielnym znacznej części ugrupowań politycznych bywaja zniekształcone przez ludzka pamięć, przez co obrastaja wieloma mitami.

W przypadku partii prawicowych będzie to legenda ruchu Solidarność i oczywiście spór o polityczną sukcesję po niej, w przypadku partii lewicowych częste sa przypadki nostalgicznego odwoływania się do okresu PRL. Z pewnością służyć temu maja hasła, często artykułowane przez działaczy SLD, iż nie wszystko 
w PRL było złe i zasługuje na potępienie. Stosunek do przeszłości jest podstawową kwestia różnicująca pozycję partii politycznych. Oczywiście kwestia rodowodu politycznego jest istotna, gdyż stanowi element świadomości politycznej każdego ugrupowania, nie ulega jednak wątpliwości, iż partie polityczne stopniowo ewoluowały pod tym względem. W związku $z$ tym badacze maja problem w postrzeganiu wizerunku partii. Subtelna metamorfoza partii politycznych, która następuje w okresie transformacji, jest procesem długotrwałym i trudnym. Nieodzownym elementem takiej przemiany jest sztuka przyswajania odmiennych poglądów oraz oswajania się $z$ nimi, co w dalszej kolejności powoduje wypieranie poprzednich nurtów przez nowo wchłonięte poglądy albo zaistnienie dwóch lub więcej odmiennych doktryn w obrębie jednej partii. Ten mechanizm adaptacji przez formacje polityczne różnorodnych idei ilustruje strategia rywalizacji partyjnej, która przyjęło się nazywać catch all. Jaskrawym przykładem tego zjawiska jest poglądowy eklektyzm: „[...] programy polskich partii sa niespójne wewnętrznie [...]. Krajowa Izba Gospodarcza przeanalizowała głosowania w obecnym Sejmie i wyszło jej, że pod względem gospodarczym SLD jest na prawicy, a PiS na lewicy. [...] Partia prawicowa $\mathrm{w}$ wymiarze kulturowo-obyczajowo-politycznym może być zgoła lewicowa gospodarczo, jak właśnie PiS czy LPR. [...] $Z$ badań sondażowych wynika, że Polacy sa generalnie niespójni, bo konserwatywni w sferze obyczajowej i prosocjalistyczni w poglądach na gospodarkę"17.

Upozycjonowanie partii $\mathrm{w}$ przestrzeni politycznej jest o wiele trudniejsze niż w latach dziewięćdziesiątych, tym bardziej że politycy uciekaja od jakichkolwiek prób klasyfikacji. Na przykład wystarczy wspomnieć postawę lidera PO z 2005 roku oraz z 2007 roku oraz szczególnie wyjatkowa - jak na liberała - znajomość problemów codziennego życia, na przykład znajomość cen pod-

\footnotetext{
${ }_{17}$ tap wyborce wszędzie, gdzie sie da!. $Z$ prof. Edmundem Wnukiem-Lipińskim, kierownikiem Katedry Socjologii Collegium Civitas, rozmawia Marcin Szymaniak, „Życie Warszawy”, 23 września 2005.
} 
stawowych produktów żywnościowych, która lider PO miał okazję zaprezentować podczas debaty telewizyjnej. $Z$ zagorzałego liberała Donald Tusk stał się politykiem zatroskanym o poziom egzystencji społecznej, a $z$ osoby akcentujaccej wolność religijna i sceptyczny stosunek wobec Kościoła przekształcił się w praktykującego katolika. Czy był to świadomy zabieg, czy też sztuczka marketingowa $\mathrm{w}$ celu przeciagnięcia elektoratu jeszcze niezdecydowanego?

Otóż zarówno PiS, jak i PO walczą na wszelkie sposoby o przywództwo na prawym skrzydle sceny politycznej, jednak posługuja się $\mathrm{w}$ tym celu poglądami zaczerpniętymi $\mathrm{z}$ odmiennych biegunów politycznych. PiS wspomaga się retoryka radykalno-populistyczna, dzięki czemu ugrupowanie braci Kaczyńskich zdominowało nie tylko konserwatywno-chrześcijańska, ale także katolicko-narodowa przestrzeń w polityce. Natomiast PO, zarówno używając haseł liberalnych, jak i akcentując wrażliwość społeczna, opiera się jednocześnie na podstawach konserwatywno-liberalnych oraz centrolewicowych. Stonowane argumenty socjalne padaja na podatny grunt i pozwalaja zbliżyć do siebie umiarkowany elektorat SLD. Obie partie, marginalizując konkurencje polityczna, stały się swoistymi monopolistami, opierając swą siłę na sympatii elektoratów obcych dotąd dla partii postsolidarnościowych.

Wszystko to sprawia, że sklasyfikowanie polskich partii politycznych jest wyzwaniem ogromnie trudnym. Dyskusyjne może być również określenie, jakim to wartościom ideologicznym partie pozostały wierne, a którym poglądom udzieliły chwilowej akceptacji, a ponadto czy nowe kwestie wpiszą się na stałe w tożsamość partyjna.

W demokracji partie polityczne nie maja szans na efektywna egzystencję w polityce, jeśli będa reprezentować jedną zwartą ideologię. Tajemnica sukcesu tkwi w tym, iż musza stanowić złożony konglomerat idei, nurtów, doktryn oraz różnorodnych osobowości, a jednocześnie trzymać na wodzy osobiste ambicje poszczególnych polityków. Utrzymanie w ryzach całego bogactwa ofert odmiennych ideologii, przy jednoczesnym zachowaniu instynktu przetrwania, jest niezwykle trudne do osiagnięcia, ale stanowi klucz do sukce- 
su wyborczego. Ten instynkt samozachowawczy oraz silne przywództwo partyjne pozwalały na integrację różnorodnych środowisk w ramach koalicji SLD w latach dziewięćdziesiątych.

\section{PO i PiS - kontynuacja idei postsolidarnościowych}

Rozdźwięk wśród partii prawicowych na polskiej scenie parlamentarnej po 2005 roku nie był niczym nadzwyczajnym w tym sensie, że podział między konserwatywno-narodowym PiS-em a umiarkowano-liberalna PO stanowi odzwierciedlenie podziałów istniejących wśród wyborców od 1989 roku. Należy zaznaczyć, iż postrzeganie PiS-u jako partii typowo konserwatywnej jest pewnym stereotypem. Podobnie jest w przypadku PO, która nie jest do końca aż tak liberalna. Ponadto oba ugrupowania sa na tyle „pojemne", że wchłonęły wiele przeciwstawnych poglądów, stając się monopolistami ideologicznymi. To spowodowało, iż obie partie stały się spadkobiercami i kontynuatorami linii partyjnych $z$ lat dziewięćdziesiątych. Otóż PiS zawiera w sobie tradycję narodowo-katolicka, która była wyznacznikiem takich formacji jak Wyborcza Akcja Katolicka, Katolicki Komitet Wyborczy „Ojczyzna” czy Liga Polskich Rodzin. Ciagłość ideologiczna daje się zauważyć w kontekście idei konserwatyzmu i chadecji, których przedstawicielami byli Porozumienie Centrum (w tym przypadku występuje kontynuacja personalna przywódców), Ruch Odbudowy Polski oraz część środowisk skupionych wokół Akcji Wyborczej Solidarność. Oprócz tego PiS jest kontynuatorem myśli etatystycznej NSZZ „Solidarność”, Konfederacji Polski Niepodległej oraz Unii Pracy Ryszarda Bugaja. Jak widać, program polityczny partii Jarosława Kaczyńskiego nie jest czymś nowym, ale stanowi zbiór poglądów, tematów i postaw zaczerpniętych $z$ wielu wcześniejszych źródeł.

Swych poprzedników politycznych ma również Platforma Obywatelska, która stanowi kontynuację ideologiczna oraz personalna 
Kongresu Liberalno-Demokratycznego. Formacja ta w 1994 roku na skutek połączenia się z Unią Demokratyczną stworzyła Unię Wolności. $Z$ powodu szerokiego spektrum ideologicznego trudno jest zaliczyć PO do konkretnego nurtu ideologicznego. Niemniej odczuwalny jest silny akcent liberalny, będący spadkiem politycznym po KLD. Liberalizm PO przejawia się przede wszystkim w decentralizacji oraz podkreślaniu praw i swobód obywatelskich. Partia Donalda Tuska czerpie inspiracje również z Unii Demokratycznej i wcześniejszego Ruchu Obywatelskiego Akcja Demokratyczna, czego przejawem jest brak wyraźnego stanowiska w kwestiach obyczajowych. Należy jednak pamiętać, iż Platforma zbudowana została także w oparciu o Stronnictwo Konserwatywno-Ludowe (wchodzace w skład Akcji Wyborczej Solidarność) oraz inne środowiska o profilu konserwatywnym. Skutkiem tego jest pojawianie się postulatów w kwestiach moralno-etycznych, w których część ugrupowania przyjmuje stanowisko religijno-tradycjonalistyczne. Analogiczna sytuacja do podziałów partyjnych na odmienne skrzydła istnieje na poziomie poglądów na gospodarkę. PO pozbyła się wyraźnie oblicza partii liberalnej, choć oczywiście sentyment do własnych korzeni pozostaje nadal silny, ale istnieje także skrzydło pozostające $\mathrm{w}$ obrębie umiarkowanego liberalizmu $z$ pewnym odcieniem socjaldemokratycznym. Rozdźwięk między liberalnym a socjaldemokratycznym obliczem PO jest wynikiem mentalnej spuścizny po Unii Wolności, a centrolewicowość stanowi także kontynuację postulatów wyrażanych przez Jacka Kuronia. Akcentowanie oprócz stereotypowego liberalizmu również wrażliwości społecznej jest wykorzystywane w strategii walki wyborczej przez partię Donalda Tuska. Dwutorowy sposób rywalizacji stanowi pewien ukłon w stronę elektoratu lewicowo-umiarkowanego, co ułatwia przyciagnięcie tej grupy wyborców w obręb oddziaływania PO.

Zarówno podział, jak i profile obu partii, które ukształtowały się w wyniku rywalizacji zapoczatkowanej w 2005 roku, nie sa czymś zupełnie nowym. Otóż przeciwstawne poglądy na kwestie ekonomiczne oraz odmienne rozłożenie akcentów w przestrzeni aksjo- 
logicznej były obecne w łonie Solidarności już na samym jej początku, a kontrast ten stał się najwyraźniejszy podczas rozpadu obozu solidarnościowego. Poruszając kwestię spójności ideowo-programowej w środowisku Solidarności, należy pamiętać, iż była to opozycja polityczna wobec rządów komunistycznych występujaca pod sztandarem związku zawodowego. Jak się później okazało, między zinstytucjonalizowana formacja polityczna a związkiem zawodowym istniała wielka różnica aspiracji oraz wyobrażeń. Odmienność poglądów i stanowisk $z$ całą ostrością ujawniła się podczas rządów Tadeusza Mazowieckiego. Otóż Solidarność w latach osiemdziesiatych stanowiła szeroka reprezentację narodową i polityczna, natomiast na skutek przemian demokratycznych stała się rzecznikiem waskiej grupy zawodowej. Związek zawodowy bardzo szybko stał się reprezentantem ludzi o zawiedzionych nadziejach, o postawie roszczeniowej i socjalnej, co w wymiarze ekonomicznym $\mathrm{w}$ naturalny sposób kłóci się $\mathrm{z}$ postulatami prawicowymi. Związek zawodowy stał się swoistym nośnikiem haseł lewicowych oraz frakcji nastawionej opozycyjnie do przemian gospodarczych polskiej transformacji. Symbol związku zawodowego stał się więc powodem destrukcji Solidarności, nie zaś elementem spajającym odmienność poglądów i oczekiwań w jednej formacji politycznej.

\section{Lewica na mapie ideologii politycznych}

Na początku lat dziewięćdziesiątych Polska lewica startowała w rywalizacji politycznej $z$ dość uprzywilejowanej pozycji: posiadała zasoby instytucjonalno-organizacyjne oraz kadrowe, czyli ludzi zaznajomionych $z$ mechanizmami polityki, obytych na salonach władzy, potrafiących się zachować w przestrzeni politycznej. Głównym elementem budowy tożsamości partyjnej lewej strony był stosunek do reform wolnorynkowych. Formacja lewicowa była głównym ugrupowaniem politycznym, które dyskontowało niezadowolenie z przekształceń ekonomiczno-gospodarczych przeprowadzanych 
przez stronę solidarnościowa. O jej sile decydował jednoznaczny i spójny wizerunek, na który miał wpływ sposób rozwiazywania wewnętrznych sporów w zaciszach gabinetów partyjnych. Pozwoliło to, w porównaniu $z$ wiecznie skłóconym obozem postsolidarnościowym, na wypracowanie wizerunku partii skutecznej i pragmatycznej. W przypadku SLD można mówić także o pewnym instynkcie samozachowawczym, który zmuszał elity lewicowe do utrzymania w ryzach swych ambicji politycznych, a także do odsunięcia partykularnych interesów w imię nadrzędnego celu, jakim było ugruntowanie się partii lewicowej w nowej rzeczywistości politycznej ${ }^{18}$.

Jednak prawdziwe problemy i wyzwania, z jakimi obóz postkomunistyczny miał się zmierzyć, nadeszły dopiero za kilka lat. Kryzys polityczny lewicy w całym swym wymiarze ujawnił się w wynikach wyborów parlamentarnych i prezydenckich w 2005 $\mathrm{roku}^{19}$. Z chwila pojawienia się nowych liderów partyjnych zauważalny był proces rozdwojenia tożsamości partyjnej. Wymiana władz partii nie oznaczała jedynie zmiany personalnej, ale zmianę pokoleniowa, a co za tym idzie - mentalna. Dotychczasowi liderzy lewicy - Włodzimierz Cimoszewicz, Krzysztof Janik, Józef Oleksy, Aleksander Kwaśniewski, Leszek Miller - nie zdołali pozostawić po sobie sprawnych i utalentowanych następców o silnym autorytecie, którzy by swobodnie brylowali pomiędzy różnymi nurtami partyjnymi, integrując wokół siebie odmienne frakcje. „Paniczny lęk Kwaśniewskiego przed Millerem i Oleksym sprawił, że w SLD nie ma dziś żadnej postaci, która mogłaby przejąc po nich pałeczkę. Abstrahując od skandali, które przez lata wokól nich narosły, trzeba powiedzieć, że dwaj byli premierzy i szefowie sojuszu

\footnotetext{
${ }_{18}$ Dokąd skręca SLD?. Ze Zbigniewem Siemiatkowskim rozmawia Wiesław Walenciak, „Przegląd" 2008, nr 15.

${ }_{19}$ Przyjęło się twierdzić, iż od momentu upublicznienia tzw. afery Rywina lewica znalazła się $\mathrm{w}$ politycznym pacie. Trudno $z$ tym poglądem się nie zgodzić, zważywszy na fakt, iż incydent korupcyjny przyniósł negatywne następstwa dla egzystencji SLD w życiu politycznym. Rozłam w partii i odejście secesjonistów pod wodza Marka Borowskiego, zmiana w przywództwie partii, która pociagnęła za sobą zmianę pokoleniową wśród najważniejszych liderów, oraz wydarzenia, które rzucały cień na rządy SLD w latach 2003-2005, znacząco osłabiły pozycję SLD na scenie politycznej.
} 
to ekstraklasa polskiego życia publicznego. To oni, a nie Olejniczak czy Napieralski, sa kwintesencja polskiej lewicy"20.

Kryzys obozu lewicowego, który nastapił po blisko piętnastu latach obecności w życiu politycznym, wynikał w dużej mierze $z$ istniejących już wcześniej słabości. Zastój ideologiczno-myślowy oraz kryzys przywódczy ujawniły się dopiero pod wpływem licznych incydentów, jak choćby afera Rywina czy afera starachowicka. Dekompozycja obozu postkomunistycznego, choć może nie w takim stopniu, jak $\mathrm{w}$ przypadku prawicy $\mathrm{w}$ latach dziewięćdziesiatych, miała wiele analogicznych cech $z$ procesem ewolucji obozu postsolidarnościowego. Obie strony spotkały się $\mathrm{w}$ połowie drogi: strona postsolidarnościowa zmierza w kierunku konsolidacji, natomiast postkomunistyczna znajduje się w kryzysie i jest na etapie odrabiania zaległości, czego obrazem jest redefinicja tożsamości partyjnej. Jeśli środowiska postsolidarnościowe formowały swa tożsamość partyjna w wyniku sporów i akcentowania odmienności, to obóz postkomunistyczny zachowywał jedność i jawił się jako monolit. Pozorna spójność była okupiona kosztem tłumienia dyskusji i sporów, które nie zawsze prowadza do rozłamu, a wzbogacaja profil ideowy poprzez wchłanianie w szeregi partyjne nowych nurtów, które zazwyczaj odświeżają poglądy. Odłożenie lub zignorowanie potrzeby dyskusji nad profilem ideowym wróciło po ponad dekadzie ze zdwojona siła. Co najmniej od rozłamu w SLD w 2004 roku lewica próbuje na nowo sformułować swój profil polityczny. Ponadto w wyniku słabej pozycji lidera w stosunku do swych poprzedników, Wojciech Olejniczak jedynie uaktywnił różnice drzemiące $\mathrm{w}$ partii.

Nic też nie pomogły próby budowy szerokiej koalicji centrolewicowej o nazwie Lewica i Demokraci. Integracja różnych środowisk o odmiennych poglądach - jak SLD versus PD - lub ze sobą skłóconych - jak SLD i secesjoniści SdPL - nie tylko nie zatarła różnic, ale je jeszcze wyostrzyła"21. Obóz lewicy, chcąc się utrzymać na po-

\footnotetext{
${ }^{20}$ M. Krzymowski, P. Krysiak: Grabarze lewicy, „Wprost” 2007, nr 40, s. 34.

21 Ibidem
} 
wierzchni życia politycznego, musiał dokonać redefinicji własnej tożsamości politycznej rozdartej pomiędzy skrzydłem antyklerykalnym, etatystycznym oraz post-PRL-owskim a skrzydłem centrolewicowym, socjaldemokratycznym i neutralnym aksjologicznie. W takim kontekście można rozpatrywać pojawienie się nowej formacji politycznej Lewica i Demokraci pod auspicjami byłego prezydenta Aleksandra Kwaśniewskiego. $Z$ jednej strony była to próba odbudowania dawnej pozycji SLD pod nowym szyldem, ale także ambitne przedsięwzięcie zbudowania szerokiej formacji centrolewicowej. W ten sposób powrócono do haseł współistnienia wolnego rynku przy zachowaniu aktywnej obecności państwa w kluczowych kwestiach ekonomiczno-społecznych. Nie był to pomysł oryginalny, gdyż podobne opinie wyrażały istniejace już podmioty PiS i PO. Dlatego miejsce, w które chciał wkroczyć LiD było już zajęte przez inne partie, ale również elektorat koalicji centrolewicowej był systematycznie podkradany przez polityczną konkurencję.

Lifting polityczny przywódców lewicowych niestety nie zmienił postaw członków umiejscowionych na niższych szczeblach drabiny partyjnej, co w przypadku niepowodzeń wyborczych uaktywniło spór między nową i tradycyjną lewica. Wartości podnoszone do tej pory przez formacje lewicowa dotyczyły kwestii socjalnych, wykluczenia społecznego, a także świeckości państwa. Innymi słowy, główna i jedynie liczaca się na lewicy partia, SLD, skupiała cała uwage na kwestii mniejszości pod względem socjalno-bytowym. $Z$ biegiem czasu zaczęły się również pojawiać inne kwestie, coraz silniej domagajace się uwagi w debacie publicznej. Do argumentów lewicowych zaliczane były kwestie antyglobalistyczne, między innymi przeciwstawianie się wyzyskowi i monopolowi wielkich korporacji, a także problemy związane $z$ ekologia lub poszanowaniem praw mniejszości seksualnych. Nastroje grup społecznych interesujących się tymi zagadnieniami sprzyjały formacji lewicowej, która jednak nie potrafiła umiejętnie wykorzystać tej sytuacji. $Z$ pewnościa było to zwiazane $z$ tym, iż w SLD istnieje dość silna grupa dawnych działaczy PZPR-owskich, dla których idee związane 
z ekologia czy obrona mniejszości swobód obyczajowych sa dość dalekie. „Większość to gładko zaczesani emeryci w znoszonych garniturach i przykrótkich krawatach. Typowy aktyw PZPR trzydzieści lat później. Żadne hasła nowoczesnej lewicy im nie w głowie. Trzy lata temu przekonał się o tym Józef Oleksy, kiedy na jednej $z$ rad wojewódzkich rzucił do sali sondażowe pytanie dotyczące legalizacji związków homoseksualnych. - Zdecydowana większość była przeciw. A jak spytałem o możliwość adoptowania dzieci przez takie pary, to rękę podniosła jedna piąta - wspomina Oleksy"22.

Paradoksalnie, jeśli chodzi o wolność obyczajową w sferze praw mniejszości seksualnych, aparat postpezetpeerowski niczym szczególnie się nie różni od zagorzałych działaczy Młodzieży Wszechpolskiej. Tak więc w łonie SLD, głównej formacji na polskiej lewicy, doszło do konfliktu między młodymi i starymi działaczami. Konflikt pokoleniowy automatycznie pociagnął za sobą spór o ważność idei. Warto powtórzyć, iż wybór między równouprawnieniem w sensie ekonomicznym lub obyczajowym nie musi oznaczać rozłamu partyjnego, lecz odpowiedź na potrzeby społeczne.

\section{Zakończenie}

Historia transformacji politycznej to nieprzerwany proces kształtowania się identyfikacji partyjnych oraz poszukiwania przez środowiska polityczne odpowiedzi na umiejscowienie własnej podmiotowości w przestrzeni politycznej. Warto przy okazji zadać pytanie, czy budowanie własnej tożsamości partyjnej jest podyktowane względami ideologiczno-programowymi czy też jest dziełem przypadku? Fakt, że polska prawica jest zróżnicowana, a między jej formacjami wyrosła przepaść nie do pokonania, jest raczej wyrazem naturalnego podziału, który istniał już od samego poczatku zaistnienia Solidarności ${ }^{23}$. Oczywiście tym, co jest stałe i niejako

\footnotetext{
${ }^{22}$ Ibidem.

${ }^{23}$ A. Michnik: Polskie kredowe koło, w: idem: Diabeł naszego czasu, Wydawnictwo Agora, Warszawa 1995, s. 341.
} 
niezmienne $\mathrm{w}$ podziale na prawicę i lewicę, jest stosunek do przeszłości, wyrażony poprzez ocenę PRL oraz relacje państwo-Kościół. Przy okazji każdych wyborów istniał wyraźny związek między wyznawanymi wartościami światopoglądowymi a poparciem udzielanym dla poszczególnych partii ${ }^{24}$.

Paradoksalnie można przyznać, iż wszelkie spory i animozje dotyczące artykułowania i realizacji poglądów we wczesnych latach III RP przysłużyły się rozwojowi polskiego pluralizmu. W wyniku debat publicznych doszło do uaktywnienia się różnych środowisk, które zaczęły szukać swojego miejsca w przestrzeni politycznej, konstruując tym samym własna tożsamość ideową. Proces kształtowania sie polskiej sceny politycznej nie był jednak łatwy, a tym bardziej spokojny i pozbawiony emocji.

\footnotetext{
$\overline{{ }^{24} \text { Por. M. Grabowska, T. Szawiel: Budowanie demokracji. Podziały spoleczne, partie politycz- }}$ ne $i$ społeczeństwo obywatelskie $w$ postkomunistycznej Polsce, Wydawnictwo Naukowe PWN, Warszawa 2001, s. 238-245.
} 